\title{
Automatic Segmentation of Trabecular Bone Based on Sphere Fitting for Micro-CT Bone Analysis
}

\author{
Kang Sun Kyung ${ }^{\dagger} \cdot$ Kim Young $\mathrm{Un}^{++} \cdot$ Jung Sung Tae ${ }^{+++}$
}

\begin{abstract}
In this study, a new method that automatically segments trabecular bone for its morphological analysis using micro-computed tomography imaging was proposed. In the proposed method, the bone region was extracted using a threshold value, and the outer boundary of the bone was detected. The sphere of maximum size with the corresponding voxel as the center was obtained by applying the sphere-fitting method to each voxel of the bone region. If this sphere includes the outer boundary of the bone, the voxels included in the sphere are classified as cortical bone; otherwise, they are classified as trabecular bone. The proposed method was applied to images of the distal femurs of 15 mice, and comparative experiments, with results manually divided by a person, were performed. Four morphological parameters-BV/TV, Tb.Th, Tb.Sp, and Tb.N-for the segmented trabecular bone were measured. The results were compared by regression analysis and the Bland-Altman method; BV/TV, Tb.Th, Tb.Sp, and Tb.N were all in the credible range. In addition, not only can the sphere-fitting method be simply implemented, but trabecular bone can also be divided precisely by using the three-dimensional information.
\end{abstract}

Keywords: Micro-Computed Tomography, Segmentation, Sphere Fitting, Trabecular Bone, Structural Parameters

\section{마이크로-CT 뼈 영상 분석을 위한 구 정합 기반 해면뼈의 자동 분할}

강 선 경 + 김 영 운 ${ }^{++} \cdot$ 정 성 태 ${ }^{+++}$

\begin{abstract}
요 약
본 논문에서는 마이크로 CT 영상에서 해면뼈의 형태학적 분석을 위하여 해면뼈를 자동 분할하는 방법을 제안한다. 제안된 방법에서는 임계값을 이용하여 뼈 영역을 추출하고 뼈의 바깥쪽 경계선을 검출한다. 뼈 영역의 각 복셀에 대하여 구 정합을 적용하여 해당 복셀을 중 심으로 하는 최대 크기의 구를 구한다. 이 구에 뼈의 바깥쪽 경계선이 포함되면 이 구에 포함된 복셀들은 치밀뼈로 분류되고 그렇지 않으 면 해면뼈로 분류된다. 제안된 방법을 쥐의 15 개 대퇴골 원위부 영상에 적용하였으며 사람이 수작업으로 분할한 결과와 비교 실험을 수행 하였다. 분할된 해면뼈에 대하여 BV/TV, Tb.Th, Tb.Sp, Tb.N의 네 가지 형태학적 지표자를 측정하였다. 회귀분석과 Bland-Altman 방법 으로 비교해본 결과 BV/TV, Tb.Th, Tb.Sp, Tb.N 모두 신뢰할 만한 수준의 범위 안에 있었다. 또한 구 정합 방법은 단순하게 구현할 수 있으면서도 3 차원 정보를 이용함으로써 해면뼈를 정확하게 분할할 수 있음을 알 수 있었다.
\end{abstract}

키워드 : 마이크로 CT, 분할, 구 정합, 해면뼈, 구조적 지표자

\section{1. 서 론}

마이크로 CT 영상은 뼈의 내부 구조를 측정 가능하게 하 는 세밀한 영상을 제공한다[1-3]. 마이크로 CT를 이용한 뼈

† 정 회 원 : 원광대학교 LINC사업단 연구교수

†† 정 회 원: 원광보건대학교 겸임교수, (주좋은정보기술 대표이사

†† 종신회원: 원광대학교 컴퓨터공학과 교수

Manuscript Received: March 11, 2014

First Revision: June 9, 2014

Accepted: June 9, 2014

* Corresponding Author: Jung Sung Tae(kyuho.shim@samsung.com)
의 구조 분석이 가능해 짐에 따라 구조 분석을 위한 도구들 이 개발되고 있다[4-6]. 뼈의 겉 영역을 치밀뼈라 하고 안쪽 영역을 해면뼈라 하는데, 치밀뼈와 해면뼈는 성질이 서로 다르므로 보통은 분리하여 분석하므로, 뼈 분석을 위한 첫 번째 단계는 해면뼈와 치밀뼈를 분리하는 작업이다. 해면뼈 와 치밀뼈의 분리 방법으로는 사람이 수작업으로 해면뼈와 치밀뼈의 경계선을 표시해주는 방법이 현재로서는 얼리 사 용되고 있다. 그런데 한 개의 뼈에 대해서도 마이크로 CT 영상에서 분석해야 할 영상의 수가 아주 많으므로 경계선을 
표시해야 하는 작업은 많은 시간을 필요로 할 뿐만 아니라 상당히 번거로운 작업이다. 경계선을 쉽게 표시하는 방법으 로는 전체 영상에 동일한 원을 적용하는 방법이 있는데, 이 방법은 경계선 표시는 간단하지만 영역별로 해면뼈의 상태 가 다르므로 구조 분석 결과의 정확도가 떨어질 수 있는 문 제가 있다.

이러한 문제점을 해결하기 위하여 치밀뼈와 해면뼈를 자 동으로 분리하는 방법들이 제안되었다. 이 중 임계값, 형태 학적 연산자, 연결 필터, 미디언 필터, 가우시언 필터들을 이 용하여 치밀뼈와 해면뼈를 자동으로 분할하는 방법이 제안 되었다[7]. 이 방법은 간단하게 구현가능하고 여러 데이터 집합에 대해 좋은 분할 결과를 보였다. 그러나 형태학적 연 산으로 인하여 치밀뼈와 해면뼈의 경계선이 정확하게 구분 되지 못할 수 있고, 새로운 데이터 집합에 대해서는 필터 파라미터를 다시 구해야 할 필요가 있을 수 있다는 문제가 있다. 명암도 히스토그램 분석을 이용하여 자동으로 계산한 임계값과 형태학적 연산을 함께 사용하는 방법이 제안되었 다[8]. 이 방법은 뼈 영상에 따라 임계값을 자동으로 계산하 는 장점이 있으나 2차원 영상에 대해 처리를 함으로써 치밀 뼈와 해면뼈의 경계선이 정확하게 구분되지 못할 수 있는 문제가 있다. 임계값을 사용하지 않고 $3 \mathrm{D}$ 텍스처 분석을 이 용한 방법이 제안되었다[9]. 이 방법에서는 먼저 $15 \times 15 \times$ 15 크기의 영역의 복셀들의 패턴을 학습하여 분류기를 생성 한다. 다음에는 분할하고자 하는 영상의 각 복셀에 분류기 를 적용하여 치밀뼈에 속하는지 해면뼈에 속하는지를 판별 한다. 이 방법은 임계값을 사용하지 않고도 분할을 수행할 수 있는 장점이 있지만 다양한 데이터 집합에 대하여 적용 가능한 분류기를 생성하는 것은 쉽지 않은 일이다.

본 논문에서는 구 정합을 이용하여 치밀뼈와 해면뼈의 경 계선을 분할하는 방법을 제안한다. 한 복셀에서 구를 정합 한다는 것은 그 복셀을 중심으로 하고 뼈 밖으로 나가지 않 으면서 최대 크기의 구를 찾는 것을 말한다. 제안된 방법에 서는 임계값을 이용하여 뼈 영역을 추출하고 치밀뼈의 바깥 쪽 경계선을 검출한다. 뼈 영역의 각 복셀에 대하여 구 정 합을 적용하여 해당 복셀을 중심으로 하는 최대 크기의 구 를 구한다. 이 구에 겉찔빼의 바깥쪽 경계선이 포함되면 이 구에 포함된 복셀들은 치밀뼈로 분류되고 그렇지 않으면 해 면뼈로 분류된다.

제안된 방법에 의하여 치밀뼈와 해면뼈가 잘 분리되는지 를 확인하기 위하여 기존에 널리 사용되는 수작업 분할 방 법과 비교하기 위해 실험용 쥐 15 마리의 대퇴골 원위부 영 상에 대하여 실험을 수행하였다. 15 개 뼈에 대해서 제안된 분할 방법과 사람의 수작업 분할 방법으로 해면뼈를 각각 분할 다음에, 해면뼈에 대하여 $\mathrm{BV} / \mathrm{TV}, \mathrm{Tb} . \mathrm{Th}, \mathrm{Tb} . \mathrm{Sp}$, Tb.N의 네 가지 형태학적 지표자를 측정하여 비교하였다. 지표자 BV/TV는 Bone Volme/Total Volume의 약자로서 전체 영역에서 뼈가 차지하는 영역의 비율을 나타낸다. 지 표자 Tb.Th는 Trabecular Thickness의 약자로서 해면뼈의 평 균 두께를 나타내고, 지표자 Tb.Sp는 Trabecular Separation
의 약자로서 해면뼈 사이의 평균 거리를 나타낸다. Tb.N은 Trabecular Number의 약자로서 단위 길이를 지나는 동안에 만나는 해면뼈의 개수를 나타낸다.

회귀분석과 Bland-Altman 방법으로 비교해본 결과 $\mathrm{BV} /$ TV, Tb.Th, Tb.Sp, Tb.N 모두 신뢰할 만한 수준의 범위 안에 있어서 구 정합 방법은 단순하게 구현할 수 있으면서 도 3 차원 정보를 이용함으로써 해면뼈를 정확하게 분할할 수 있음을 알 수 있었고 수작업 분할 대신에 사용되어도 문 제되지 않을 수준으로서 본 논문에서 제안된 방법은 기존의 수작업의 번거로운 일을 덜어 줄 수 있을 것으로 분석된다.

\section{2. 구 정합에 의한 분할}

본 논문에서 사용한 CT 영상은 NFR Polaris-G90(나노포 커스레이, 대한민국) 장비를 사용하여 촬영하였다. $\mathrm{X}$-레이 소스의 전압은 $40 \mathrm{kVp}$ 로 설정하여고 전류는 $100 \mu \mathrm{A}$ 로 설정하 여 촬영되었으며, 복셀의 크기는 $6.879 \times 6.879 \times 6.879 \mu \mathrm{m} 3$ 로 설 정하여 1024장을 촬영하였다. 촬영된 DICOM 파일은 Xelis (인피니트, 대한민국) 소프트웨어를 통해 3D 영상으로 재구 성되었다. 마이크로 $\mathrm{CT}$ 에 의해 촬영된 영상과 Xelis에 의해 $3 \mathrm{D}$ 재구성된 영상이 그림 $1(\mathrm{a})$ 와 그림 $1(\mathrm{~b})$ 에 나타나 있다.

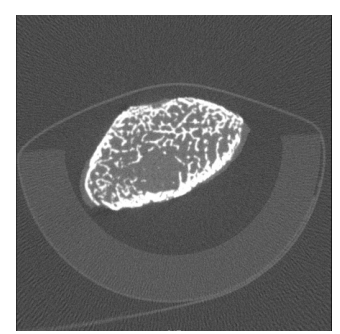

(a)

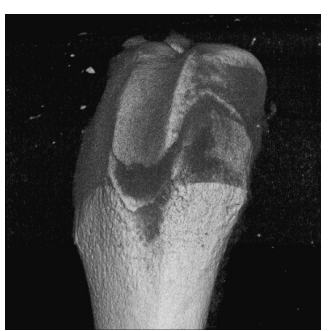

(b)
Fig. 1. Bone image used for experimentation (a) Micro CT image (b) Reconstructed 3D image with Xelis

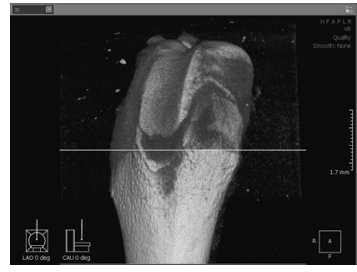

(a)

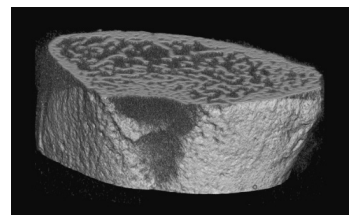

(b)
Fig. 2. Analysis region setting

(a) Specification of start location of analysis region (b) Analysis region image

해면뼈에 대한 지표자 분석은 촬영된 뼈 영상 전체에 대 해서 수행하는 것이 아니라 일반적으로 성장판 아래의 일정 구간에 대하여 수행한다. 본 논문에서는 Xelis 소프트웨어에 서 성장판 아래에 그림 2 와 같이 시작 위치를 지정하면 그 곳으로부터 $2 \mathrm{~mm}$ 에 해당하는 영역을 자동으로 추출하여 분 
석하였다. 복셀의 크기가 각 방향으로 $6.879 \mu \mathrm{m}$ 이므로 $2 \mathrm{~mm}$ 에 해당하는 영역은 291장의 슬라이스가 된다. 그림 2(a)에 는 분석 영역의 시작 위치를 설정한 예가 나타나 있고 그림 2(b)에는 설정된 분석 영역의 예가 나타나 있다.

제안된 알고리즘에서는 먼저 식 (1)과 같이 주어진 임계 값을 이용하여 뼈 영역을 추출한다. 여기에서, $v(x, y, z)$ 는 $(\mathrm{x}, \mathrm{y}, \mathrm{z})$ 에서의 voxel 값이고 $\mathrm{TH}$ 는 주어진 임계값이다. 그 림 3(a)는 원 영상이 나타나 있고 그림 3(b)에는 식 (1)에 의해 이진화된 영상이 나타나 있다.

$$
A(x, y, z)= \begin{cases}0 & v(x, y, z)<T H \\ 255 & v(x, y, z) \geq T H\end{cases}
$$

단순하게 임계값을 적용하면 뼈 영역만 완벽하게 추출되 지 않고 잡음이 생긴다. 이러한 잡음을 제거하기 위해서는 뼈가 서로 연결되어 있다는 특성을 이용한다. 추출된 뼈 영 역에서 3 차원으로 서로 연결된 영역들을 추출하고 그 중에 서 가장 큰 영역만 남기고 나머지는 버림으로써 잡음을 제 거하였다. 그림 3(c)에는 이와 같은 방법으로 잡음이 제거된 영상이 나타나 있다.

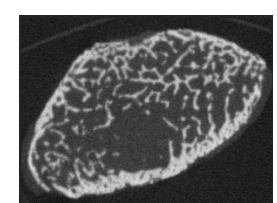

(a)

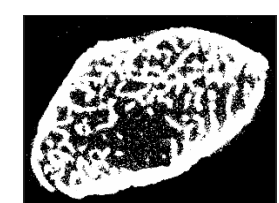

(b)

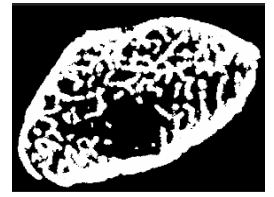

(c)

Fig. 3. Binarization and noise removal (a) Original image (b) Binarized image (c) Noise removed image

본 논문에서 제안하는 구 정합 방법에서는 치밀뼈의 외곽 선 위치를 필요로 한다. 외곽선은 뼈 영역의 내부의 구멍을 메운 다음에 각 슬라이스의 뼈 영역에 대해 침식 연산을 적 용하면 제거되는 복셀들을 찾음으로써 구할 수 있다. 그런 데 치밀뼈의 일부가 약해져서 틈이 있는 경우에는 구멍이 정상적으로 메워지지 않고 잘못된 치밀뼈 외곽선 위치를 얻 게 된다. 따라서 틈을 메워주어야 한다. 본 논문에서는 형태 학적 연산을 이용하여 틈을 메웠다. 앞에서 구한 뼈 영역에 대해 내부의 구멍을 메운 영상을 B라 하자. 그림 4(a)에는 그림 3(c)의 영상에 대해 내부를 채운 영상이 나타나 있다. 치밀뼈에 틈이 있어 내부가 완전히 채워지지 않은 것을 볼 수 있다. 이러한 영상 $\mathrm{B}$ 를 복사한 영상에 팽창 연산을 적용 한 다음 침식 연산을 적용한 영상 $\mathrm{C}$ 를 구한다. 그림 $4(\mathrm{~b})$ 에 는 그림 $4(\mathrm{a})$ 영상에 팽창연산과 침식연산을 적용한 결과가 나타나 있다. 이때 팽창 연산의 필터 크기가 $\mathrm{N}$ 일때 침식 연
산의 필터 크기를 $\mathrm{N}+1$ 로 설정하였다. 팽창 연산에 의해 틈 이 메워지고 침식 연산에 의해 원래 크기로 돌아오는데, 메 워진 틈은 다시 벌어지지 않고 메워진 상태를 유지하게 된 다. 최종적으로 식 (2)와 같이 $\mathrm{B}$ 영상과 $\mathrm{C}$ 영상의 합집합을 구하여 틈이 메꾸어지고 내부가 채워진 뼈 영역 영상을 구 하게 된다.

$$
\mathrm{D}=\mathrm{B} \mathrm{U} \mathrm{C}
$$

식 (2)를 적용한 결과 영상에 그림 4(c)에 나타나 있다. C 영상을 구할 때에 침식 연산의 필터 크기를 더 크게 하는 이유는 $\mathrm{C}$ 영상을 $\mathrm{B}$ 영상보다 작게 함으로써 $\mathrm{B}$ 영상과 $\mathrm{C}$ 영상 의 합집합 영상에서 틈새 부분만 $\mathrm{C}$ 로부터 경계선을 받아오 고 나머지는 $\mathrm{B}$ 로부터 경계선을 받아오도록 하기 위함이다.

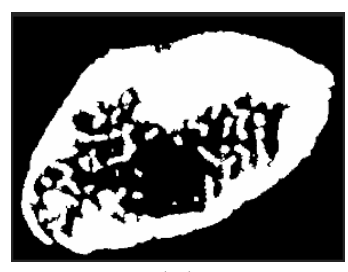

(a)

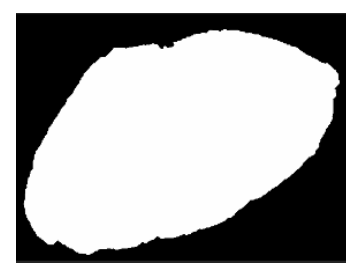

(b)

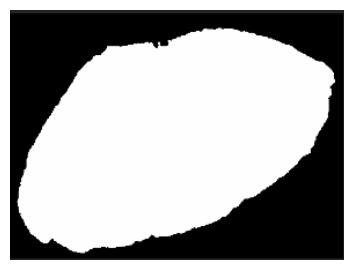

(c)

Fig. 4. Region extraction of interior filled bone (a) Interior filled image (b) Dilated and eroded image (c) Unioned image

그 다음에는 각 슬라이스별로 치밀뼈의 외곽선을 구한다. 틈새와 내부가 채워진 뼈 영상을 구한 다음에는 각 슬라이 스 별로 뼈 영역에 대해 침식 연산을 적용하면 제거되는 복 셀들을 찾음으로써 치밀뼈의 외곽선을 구할 수 있다. 그림 $4(\mathrm{c})$ 에 나타나 있는 슬라이스 영상 $\mathrm{D}$ 에 대하여 침식연산을 적용하여 영상 $E(D)$ 를 구하고 이를 반전시킨 영상 $E(D)^{C}$ 를 그림 5(a)에 나타나 있는 바와 같이 구한다. 그 다음에 식 (3)과 같이 $E(D)^{C}$ 와 영상 $D$ 와 교집합을 수행하여 경계 선 영상을 구할 수 있다.

$$
V=E(D)^{C} \cap D
$$

식 (3)을 적용한 결과 영상이 그림 5(b)에 나타나 있다. 이와 같은 일련의 과정을 거쳐서 치밀뼈의 외부 경계선을 검출하게 된다.

외곽선을 찾은 다음에는 뼈 영역의 각 복셀에 대하여 구 정합늘 수행한다. 구 정합이란 한 복셀을 중심으로 하면서 뼈 영역 내부에서 존재하는 최대 크기의 구를 찾는 것이다. 
그림 6에는 구 정합 예가 나타나 있다. 그림 6(a)은 3차원 상에서 양쪽 면의 절단면으로 본 장면이고 그림 $6(\mathrm{~b})$ 는 2 차 원으로 본 장면이다. 구 정합으로 구한 최대 크기의 구에 치밀뼈의 외곽선의 복셀이 포함되면 이 구에 속한 복셀들은 모두 치밀뼈에 속한 것으로 분류된다.

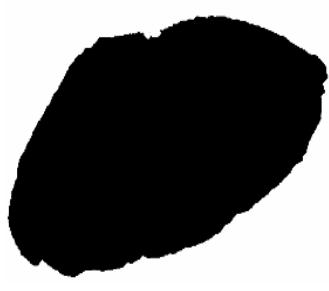

(a)

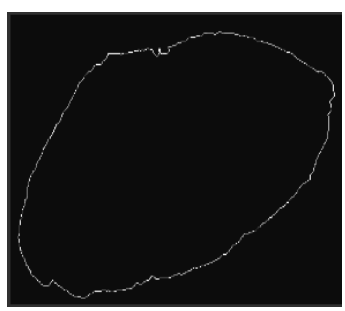

(b)
Fig. 5. Outer boundary extraction of cortical bone (a) Eroded and negated image (b) Boundary image

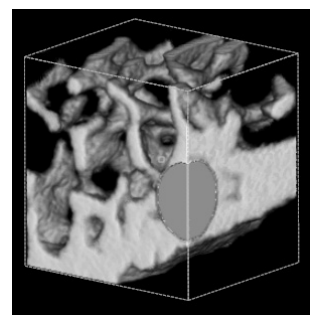

(a)

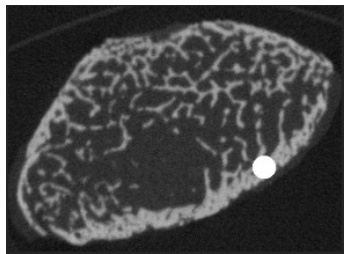

(b)
Fig. 6. Sphere fitting example (a) Three dimensional view (b) Two dimensional view

각 복셀에 대한 구 정합을 마치고 나면 치밀뼈와 해면뼈 영역이 구해진다. 그림 7(a)에는 치밀뼈의 영역이 표시되어 있고 그림 7(b)에는 해면뼈의 영역이 표시되어 있다.

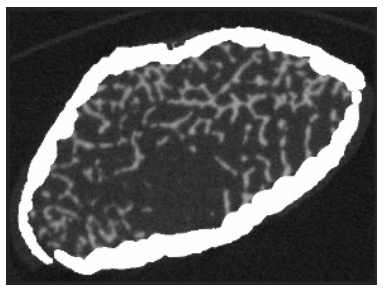

(a)

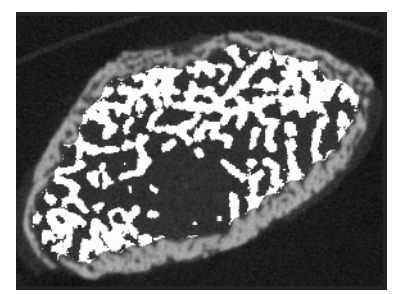

(b)
Fig. 7. Sphere fitting result for a slice (a) Cortical bone region (b) Trabecular bone region

\section{3. 실험 결과}

제안된 방법의 성능을 검증하기 위해 실험용 쥐 15 마리의 대 퇴골 원위부에 대해 실험을 수행하였다. 실험대상은 15 마리의 쥐는 세 그룹으로 구성되어 있는데, Control 그룹(n=5)은 아무런 처치를 하지 않은 그룹이고, LPS 그룹(n=5)에는 리포다당류 (lipopolysaccharide)라는 골다공증 유발 인자를 투여한 그룹이
며, LPSE 그룹(n=5)에는 리포다당류와 함께 골소실 예방 인 자인 에모딘(emodin)을 함께 투여한 그룹이다. 이 뼈들에 대해서 제안된 분할 방법과 사람의 수작업 분할 방법으로 해면뼈를 각각 분할 다음에, 해면뼈의 구조적 지표자인 BV/TV, Tb.Th, Tb.Sp, Tb.N를 추출하여 비교하였다.

$\mathrm{BV} / \mathrm{TV}$ 는 분할된 해면뼈가 위치하는 전체 영역과 그 안 에서 실제 해면뼈가 차지하는 영역의 부피를 계산하여 구하 였다. 부피는 VTK(Visulaization Toolkit)의 라이브러리 함 수 중 3 차원 메시의 부피를 계산하는 함수를 사용하여 구했 다[10]. 본 논문에서는 3 차원 상에서 해면뼈 영역에 구를 정 합하여 해면뼈의 두께 Tb.Th를 구하는 방법을 이용하였다 [11]. Tb.Sp도 Tb.Th와 마찬가지로 구 정합을 이용한다. Tb.Th를 구하기 위해 해면뼈 내부의 점들에 대해 구 정합 을 하였지만, Tb.Sp의 경우에는 해변뼈가 차지하는 전체 영 역에서 빈 공간의 점들에 대해 구 정합을 적용한다. 해변뼈 가 차지하는 전체 영역의 빈 공간 영역은 해면뼈 영역을 반 전시켜서 구한다. Tb.N은 Tb.Th와 Tb.Sp를 이용하여 식 (4)와 같이 구하였다.

$$
T b . N=\frac{1}{T b \cdot T h+T b \cdot S p}
$$

모든 뼈들에 대해 1024 슬라이스가 스캔되었으며, 그 중에 서 성장판 아래 부분의 291 슬라이스를 선택하여 분석하였 다. 수작업 분할은 한사람이 수행하였으며 치밀뼈 안쪽 표면 근처에 윤곽선을 그려서 분할을 하였다. 제안된 방법에서 필 요로 하는 뼈와 조직 사이의 임계값은 전체 뼈에 대해 동일 한 값을 사용하였으며, 이 값은 CT 장비나 쵤영 조건에 따 라 달라질 수 있으므로 스캔된 영상을 조사하여 결정하였다. 해면뼈의 구조적 지표자는 3 차원에서 직접 측정하는 방법을 사용하였다. 제안된 방법과 수작업 방법의 결과를 비교하기 위해 Bland-Altman 방법을 이용하였다[12]. 또한 선형 회귀 분석(inear regression) 방법을 이용한 비교도 수행하였다.

사람이 수작업으로 분할한 결과와 제안된 자동 분할 방법 의 결과를 시각적으로 비교하였다. 그림 8에는 세 그룹별로 하나의 뼈에 대하여, 분석 대상 뼈 영상, 분할된 치밀뼈 영 상, 분할된 해면뼈 영상이 나타나 있다. 수작업 분할 결과와 자동 분할 방법은 거의 유사한 결과를 보였다. 치밀뼈 영상 에서 밝은 부분이 치밀뼈와 해면뼈가 분리된 면인데, 구 정 합 방법은 분리 면이 부드럽고 좁은 반면에 볼록한 것을 볼 수 있고 수작업 방법은 분리 면이 넓고 평평한 것을 볼 수 있다. 구 정합 방법은 치밀뼈와 해면뼈가 구의 경계면에서 분리되므로 분리면이 볼록해지는 것이고, 수작업으로 분리 할 경우에는 치밀뼈와 해면뼈가 만나는 영역에서 윤곽선을 그려서 분리를 하게 되는데, 윤곽선은 직선을 연결하여 생 성되므로 분리면이 평평하게 된다. 수작업에 의한 분할은 슬라이스별로 일관성을 유지하기가 어려워 분리면이 자동 분할보다는 거칠어진다. 구 정합 방법의 분리면이 좁다는 것은 치밀뼈의 안쪽 표면을 수작업보다 더 잘 보존하는 것 으로 해석할 수 있다. 

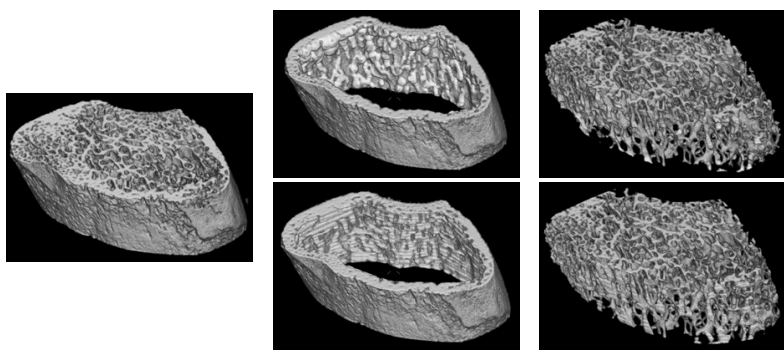

(a)
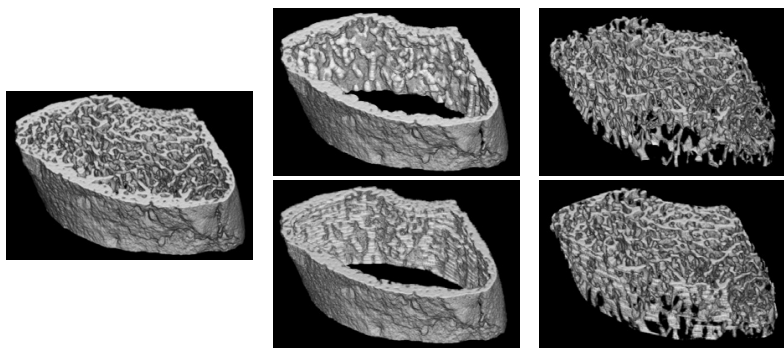

(b)
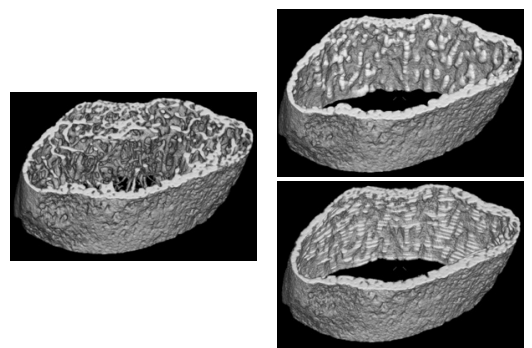

(c)

Fig. 8. Segmentation result (a) Control group's sample (b) LPSE group's sample (c) LPS group's sample

15 개 뼈에 대하여 제안된 방법과 수작업을 사용하여 해면 뼈를 분할하고 구조적 지표자를 추출하였다. 분석한 네 가 지 지표자 모두에 대하여 이들 사이의 회귀분석은 표본 결 정계수, $R^{2}$ 은 그림 9 에 나타나 있듯이 모두 0.99 이상으로 매우 높았다. 또한, 회귀의 기울기와 절편도 각각 1 과 0 에 가까워서, 두 방법은 상당히 일치된 결과를 생성함을 알 수 있다. Bland-Altman 분석은 수작업과 구 정합 방법의 일치 도가 맏아들일 만한 수준에 있음을 보여주고 있다. $\mathrm{BV} / \mathrm{TV}$ 의 경우 평균 차이가 $1.83 \%$ 이고 일치의 상한이 $5.98 \%$ 이며 일치의 하한이 $-2.32 \%$ 이다. 이는 수작업의 값이 구 정합의 값 보다 $5.98 \%$ 큰 값과 $2.32 \%$ 작은 값의 범위 내에 값을 가진다는 것을 의미하고 평균에서 $\pm 4.15 \%$ 범위이므로 이정 도의 오차는 받아들일 만하다. Tb.Th, Tb.Sp, Tb.N에 대한 이 오차 범위는 각각 $\pm 1.72 \%, \pm 0.92 \%, \pm 0.78 \%$ 로서 일치 도가 높다. Bland-Altman 분석은 시스템적 편향이 약간 있 는 것을 보여주고 있는데, BV/TV, Tb.Th, Tb.Sp는 수작업 이 약간 큰 값을 보였고 Tb.N은 구 정합 방법이 약간 큰 값을 보였다. 그러나 구조적 지표자들 모두 평균 상대 차이 가 $2 \%$ 라는 아주 작은 범위 내에 있어서 시스템적 편향이 그리 크지 않음을 보여 주고 있다.

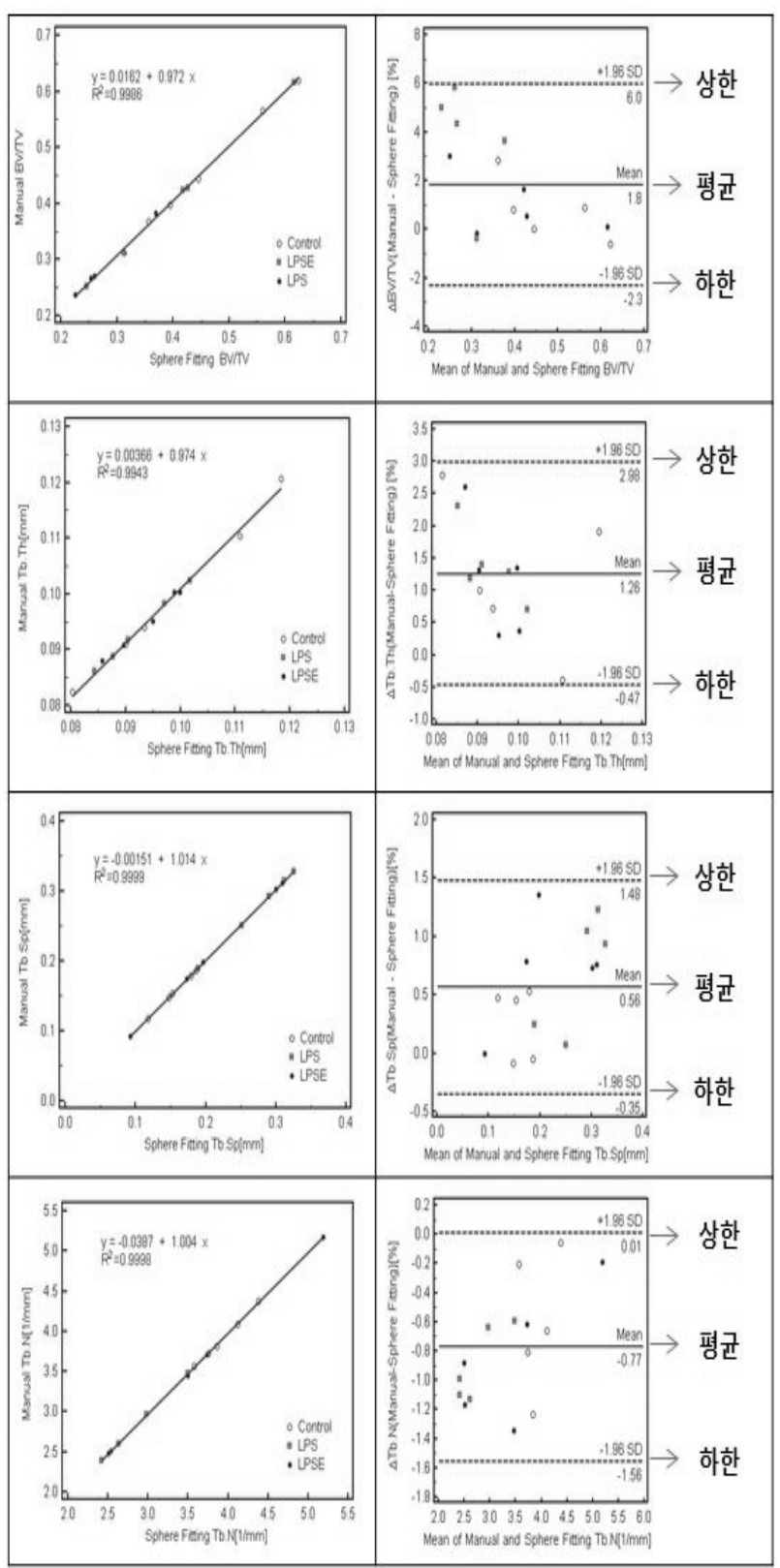

Fig. 9. Regression analysis and Bland-Altman analysis result for structural parameters

\section{4. 결 론}

본 본문에서는 마이크로 $\mathrm{CT}$ 데이터를 위한 새로운 해면 뼈 자동 분할 방법을 제안하였다. 제안된 방법은 sphere fitting을 이용하여 3차원 상에서 치밀뼈와 해면뼈를 구별함 으로써, 마이크로 CT 데이터에 대해 해면뼈를 정확하게 분 할할 수 있었다. 제안된 방법으로 자동 분할된 해면뼈와 수작 업으로 분할한 해면뼈에 대하여 네 가지 형태학적 지수 BV/TV, Tb.Th, Tb.Sp, Tb.N를 계산하고 회귀분석과 BlandAltman plot 방법으로 비교한 결과 두 방법은 서로 대치해 서 사용할 수 있을 정도로 유사하였다. 제안된 방법과 수작 
업 방법을 비교해본 결과 통계적으로 서로 대치해서 사용 할 만한 수준의 유사도를 보여, 제안된 방법이 기존의 수작 업으로 인한 많은 번거로움을 해소시킬 수 있을 것으로 분 석된다.

\section{Reference}

[1] Y. Jiang, J. Zhao, E. Y. Liao, R. C. Dai, X. P. Wu, H. K. Genant, "Application of micro-CT assessment of 3-D bone microstructure in preclinical and clinical studies," Journal of Bone and Mineral Metabolism, Vol.23, No.1, Supplement, pp.122-31, 2005 .

[2] A. Laib, J. L. Kumer, S. Majumdar, N. E. Lane, "The temporal changes of trabecular architecture in ovariectomized rats assessed by MicroCT," Osteoporos International, Vol.12, No. 11, pp.936-941, 2001.

[3] R. Muller, T. Hildebrand, P. Ruegsegger, "Non-invasive bone biopsy: a new method to analyse and display the threedimensional structure of trabecular bone," Physicsin Medicineand Biology, Vol.39, No.1, pp.145-164, 1994.

[4] C. Graeff, F. Marin, H. Petto, O. Kayser, A. Reisinger, J. Peña, P. Zysset, C. C. Glüer, "High resolution quantitative computed tomography-based assessment of trabecular microstructure and strength estimates by finite-element analysis of the spine but not DXA, reflects vertebral fracture status in men with glucocorticoid-induced osteoporosis," Bone, Vol.52, No. 2, pp.568-577, 2013.

[5] I. H. Parkinson, D. Forbes, P. Sutton-Smith, and N. L. Fazzalari, "Model-Independent 3D Descriptors of Vertebral Cancellous Bone Architecture," Journal of Osteoporosis, Vol. 2010, Article ID. 641578, 2010.

[6] M. Stauber and R. Müller, "Volumetric spatial decomposition of trabecular bone into rods and plates - A new method for local bone morphometry," Bone, Vol.38, No.4, pp.475-484, 2006.

[7] H. R. Buie, G. M. Campbell, R. J. Klinck, J. A. MacNeil, S. K. Boyd, "Automatic segmentation of cortical and trabecular compartments based on a dual threshold technique for in vivo micro-CT bone analysis," Bone 41, pp.505-515, 2007.

[8] Rizzo G., Tresoldi D., Scalco E., Mendez M., Bianchi A. M., Moro G. L., Rucinacci A., "Automatic Segmentation of Cortical and Trabecular Components of Bone Specimens by pQCT," 30Th Annual International IEEE EMBS Conference, pp.486-489, 2008.

[9] Alexander Valentinitsch, Janina M. Patsch, Julia Deutschmann, Claudia Schueller-Weidekamm, Heinrich Resch, Franz Kainberger, Georg Langs, "Automated threshold-independent cortex segmentation by 3D-texture analysis of HR-pQCT scans," Bone 51, pp.480-487, 2012.
[10] Kitware Inc., "VTK User's Guide," Kitware Inc., 2010.

[11] T. Hildebrand and P. Rüegsegger, "A new method for the medel-independent assessment of thickness in threedimensional images," Journal of Microscopy, Vol.185, Pt.1, pp.67-75, 1997.

[12] Bland J. M., Altman D.G., "Statistical method for assessing agreement between two methods of clinical measurement," The Lancet, pp.307-310, 1986.

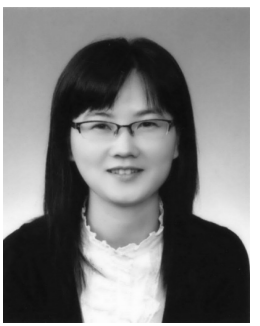

강 선 경

e-mail :doctor10@wku.ac.kr

2000년 원광대학교 전기·전자공학(공학사)

2004년 원광대학교 정보·컴퓨터교육학과 (교육학석사)

2010년 원광대학교 컴퓨터공학과(공학박사) 2010년 2014년 (주)좋은정보기술 연구소장

2011년 2013년 원광보건대학교 겸임교수

2013년 2014년 대덕대학교 겸임교수

2014년 현 재 원광대학교 LINC사업단 연구교수

관심분야 : 영상처리, $\mathrm{HCI}$, 패턴인식, 임베디드시스템

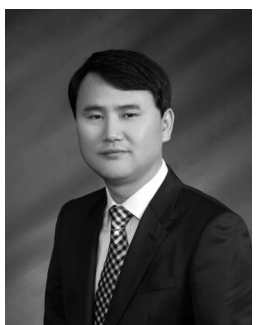

김 영 운

e-mail : yukim@goodit.kr

2003년 원광대학교 컴퓨터정보통신공학부 (공학사)

2005년 원광대학교 컴퓨터공학과(공학석사) 2012년 원광대학교 컴퓨터공학과(공학박사)

현 재 원광보건대학교 겸임교수, (주)좋은정보기술 대표이사 관심분야: 영상처리, 패턴인식, 윕서비스

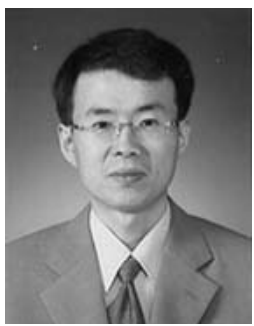

정 성 태

e-mail : kyuho.shim@samsung.com 1987년 서울대학교 컴퓨터공학과(공학사) 1989년 서울대학교 컴퓨터공학과(공학석사) 1994년 서울대학교 컴퓨터공학과(공학박사) 1995년 현 재 원광대학교 컴퓨터공학과 교수

관심분야: 영상인식, 영상처리, 컴퓨터 그래픽스 